(RESEARCH ARTICLE)

\title{
The plants traded at the nursery of Jatikarya, Bekasi District, West Java Province, Indonesia
}

\author{
Silalahi Marina * \\ Prodi Pendidikan Biologi, Fakultas Keguruan dan Ilmu Pendidikan, Universitas Kristen Indonesia.
}

Publication history: Received on 01 August 2019; revised on 22 August 2019; accepted on 05 September 2019

Article DOI: https://doi.org/10.30574/gscbps.2019.8.3.0147

\begin{abstract}
Nursery is a places to buy, sell, care, and maintain various types of beneficial plants. The type and value of selling plants varies between regions depending on the needs and supply. This study aims to determine the species and economic value of plants traded in the nursery of Jatikarya, Bekasi District, West Java Province, Indonesia. Theresearch was conducted a survey and interviews to the nursery owners or employees. The list of questionnaire were local name of the plants, source of acquisition, supplying, purchasing and selling price of each plants. A number of 130 species belonging 96 genera and 56 families traded at the Jatikarya nursery and the selling price was about 5,000 - 5.000,000 IDR. The trading plants uses as ornament, sources of fruit, ground cover, and shade. The selling value of each species depends on the size, supply, age, method of breeding, and maintenance. The bonsai plants such as Korean banyan (Ficus campanulata/ Moraceae) and anting putri (Wrightia religiosa/ Apocynaceae) have expensive. The rambutans (Nephelium lappaceum) and guavas (Psidium guajava) are the most popular of fruit plants. The krokots (Portulaca glandiflora) and lili paris (Chlorophytum comosum) are easy to propagate with affordable prices (5,00010,000 IDR) per unit. In order to increase the productivity of nursery and conservation, it is important to promote and to socialize the role of plants.
\end{abstract}

Keywords: Nursery; Jatikarya; Ficus campanulata

\section{Introduction}

Indonesia has a diversity of around 30,000 plant species. The distribution of biodiversity between in the region, island and country is varied. Based on the biogeography of plants, indonesia is divided into three zones, namely is western Malesiana, central Malesiana and eastern Malesiana [1]. The Dipterocarpaceae such as meranti (Shorea spp.) are found in western Malesiana, pandan (Pandanus spp) and matoa (Sapindaceae) are found in the eastern Malesiana.

The use of plants by human results trading plants by local communities [2]. The transaction of buying and selling plants can be found in the traditional markets, modern markets and nursery. Silalahi et al [3] stated that the buying and selling of medicinal plants in the Kabanjahe traditional market had been carried out for decades and found more than 240 species of medicinal plants to be traded. Various benefits from buying and selling have grown, among others, as a source of income, exchange of local knowledge and preserving local wisdom [4].

In the "traditional markets and supermarkets are used by local communities to buy and to sell plants for some purposes such as fruits, vegetable, staple food [5], while in the nursery are also carried out nurseryes and maintenance of plants that are traded [6-7]. Its shows that in the nursery have thev very complex of problem, so its need the plant management which resulted the sustainable the nursery [8].

\footnotetext{
${ }^{*}$ Corresponding author

E-mail address: marina_biouki@yahoo.com
} 
Various types of plants are traded in nursery such as ornamental plants, fruit-producing plants, and shade plants [8]. Plants that are traded in nursery are thought to differ from one location to another. Some factors that are thought to influence include capital [9], plant habitus [10], and nursery size [7]. Singh et al [10] stated that plant species with tree seeds in nursery in urban areas were less than those in peri urban nursery.

Since the 2000s, in Jakarta area including Bekasi begun nursery to answer the needs of plants by residents of Jakarta and its surroundings. Silalahi and Sihotang [11] stated that trading plants in nursery in Bekasi are dominated by herbal plants because they had smaller size and faster propagation. The people in the city have a narrow land, so they rarely use trees as garden plants.

Jatikarya is of the regional of the Bekasi district that has prospects for buying and selling various types of plants. Until now, the research of nursery trading plant is still limited, even though the prospects for nurseryes in the economic and ecological fields need to be studied as an effort to preserve biodiversity and as a source of income. This study aims to determine the trade and diversity of nursery plants in Jatikarya, Bekasi District. The results of this study are expected to become one of the plants database.

\section{Material and methods}

\subsection{Data collection in the field}

To find out the nursery types at Jatikarya, surveys and observations were conducted. The data Plants were photos, local names, habitus and sale value. To complete the data, the identity of the selection or employee in the nursery is also asked, including name, age, gender and ethnicity. Identification was done by comparing the types of plants obtained with the Flora of Java Volume II-III book [12-13].

\subsection{Analysis of data}

Data analysis is carried out qualitatively including the types of plants being traded, habitus and selling prices. Analysis of plant diversity carried out descriptively by grouping plants based on habitus (trees, shrubs, herbs), benefits (ornamental plants, shade, and other functions), genus and family.

\section{Results and discussion}

\subsection{Description of traders in nursery of Jatikarya}

The traders nurseries of Jatikarya are Javanese, Sundanese and Betawi ethnic that has been trading for 8-31 yeas 8-31 years. All traders are male, aged 38-50 years old. Every nursery has employees whose job is to preserve plants while helping buy-sell transactions. Buying Plant and selling transactions at Jatikarya Nursery starts from 08.00-17.00.
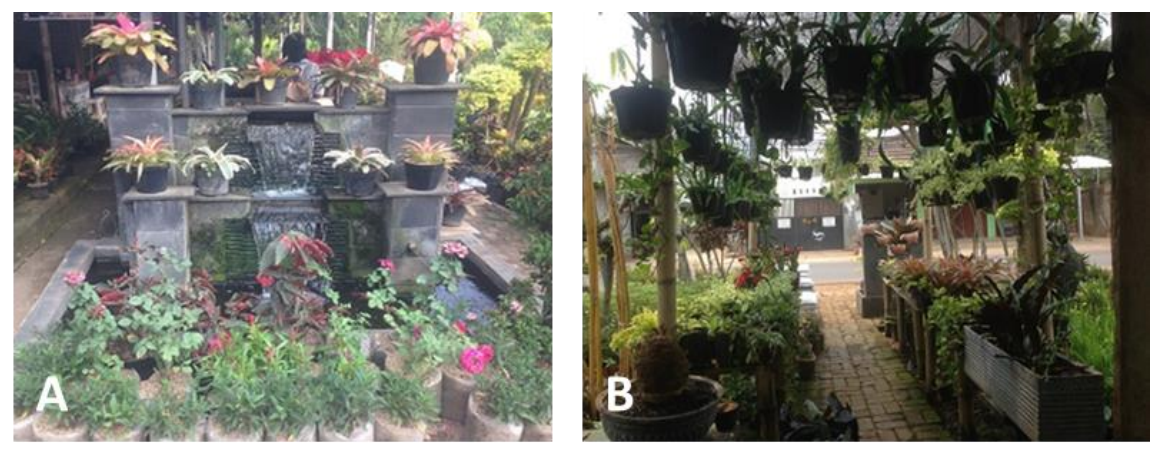

Figure 1 Structuring of plants at the nursery of Jatikarya, Bekasi District, West Java Province, Indonesia. A. Display the front by arranging a simple landscape; B. Display by arranging plants by hanging plants on the nursery ceiling

The number of employees' 1-3 people depends on the size and amount of work. To attract customers, the owners or employees organize the front display of the nursery attractively by using its own plants while at the same time making efficient use of space and land (Figure 1a). Placement of plants in nursery space is adjusted to the needs of the sun, size, and the need for water. Small plants that require high humidity are hung on the nursery ceiling and protected from direct light using paranet (Figure 1b). 
The nursery also provide various other materials such as pots, planting media, seeds, fertilizers and other plant maintenance tools (roasting, spray, ornamental stones) to customers (Figure 2). When viewed from the volume, the sales of planting media and pots are most in demand and the size and type of pots are adjusted to the type of plants to be cultivated. Potted plants with a diameter of 50-100 cm are used for fruit trees, while pots with a diameter of 10-30 $\mathrm{cm}$ are used for ornamental plants.

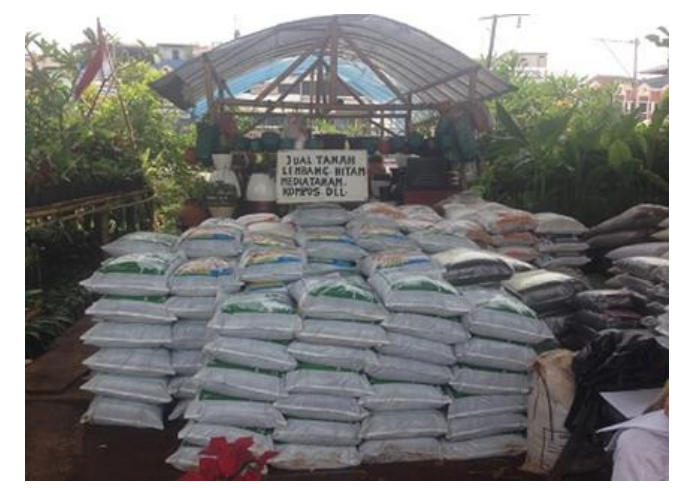

Figure 2 The planting media (organic fertilizer) and pots are traded at the nursery of Jatikarya, Bekasi District, West Java Province, Indonesia

In addition to buying and selling transactions at the nursery, weeding, fertilizing, and other treatments are also carried out. Sihotang et al [7] (2019) stated that for efficiency in nursery management good management is needed so that the continuity and development of the nursery can be improved. In nurseries some traders also use plastic waste from mineral water, which can directly reduce waste (Figure 3). Some plants are propagation with cuttings such as wijaya kusuma, cactus and Draecaena. Aglaonema spp. bred by separating some buds that have been formed. The nurseryes carried out by nursery owners are mostly in the form of stem cuttings and by the separation of the parent plant clumps. It aims to minimize production costs so that the selling price can be reduced.
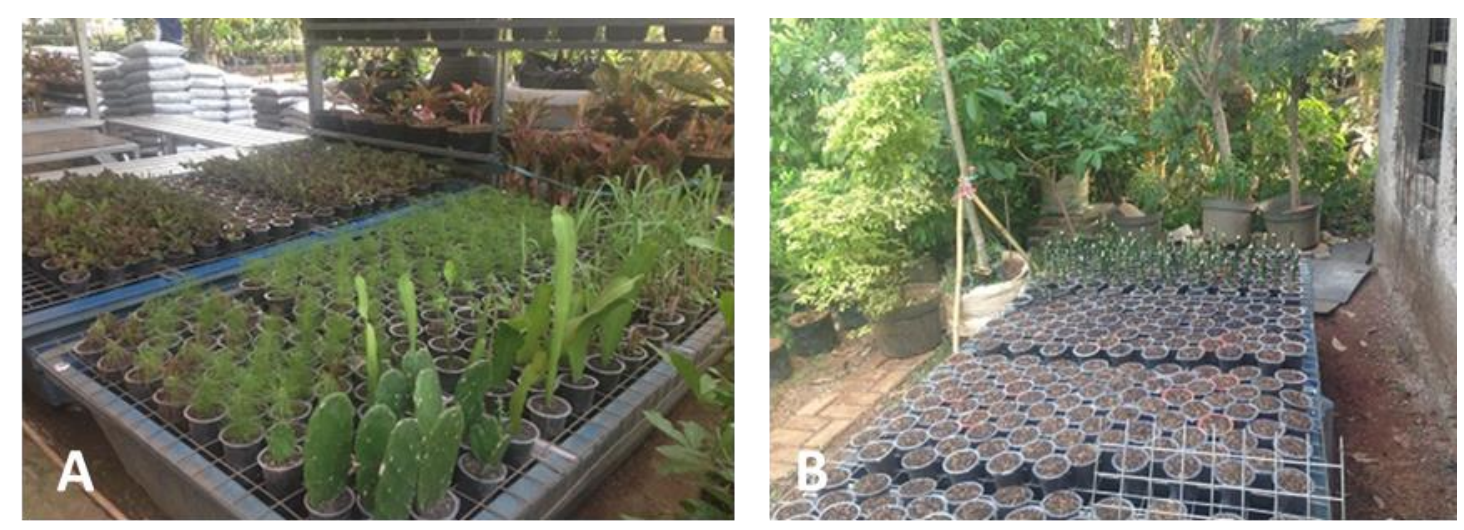

Figure 3 The activities at the nursery of Jatikarya, Bekasi District, West Java Province, Indonesia. A. Nurseryes by separating clumps and stem cuttings. B. Waste plastic used mineral water as a nursery container.

\subsection{Diversity of Plants}

The research found 130 species belonging to 96 genera and 56 families (Figure 4). Most of the plants belonging the Araceae, Arcaceae, and Asparagaceae families (Table 1). The Araceae plants are the ornamental plants that have attractive leaves characters such as Aglaonema spp and Anthurium spp. The Aglaonema spp are the plant have colorful leaves with a relatively expensive selling price $(200,000$ IDR) and many devotees. 


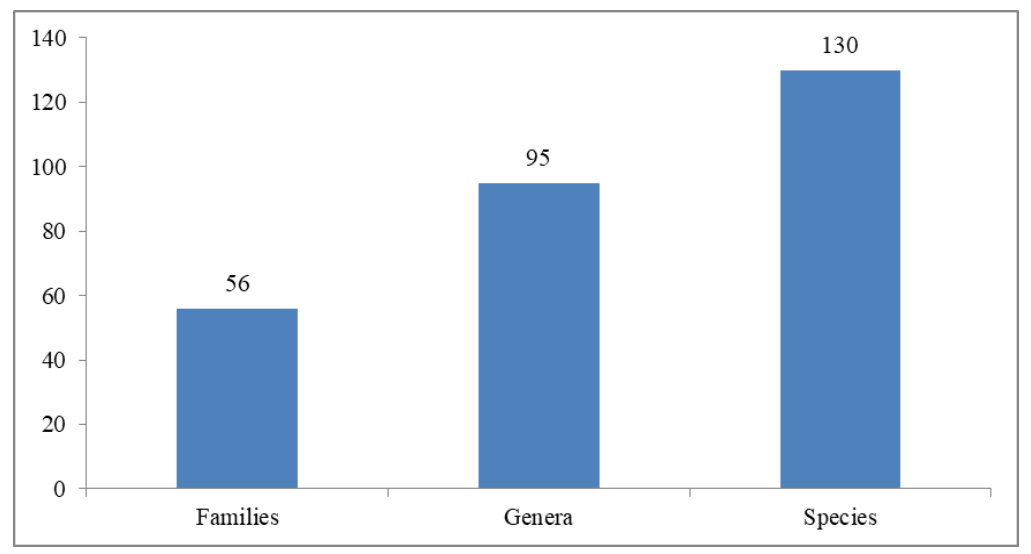

Figure 4 The number of families, genera and species are traded at the nursery of Jatikarya, Bekasi District, West Java Province, Indonesia.

Table 1 Local names, scientific names and benefits of plants at the nursery of Jatikarya, District, West Java Province, Indonesia

\begin{tabular}{|c|c|c|c|}
\hline Family & Scientific name & Local name & Uses \\
\hline \multirow[t]{2}{*}{ Adiantaceae } & Adiantum sp.1 & Suplir dolar & Ornamental plant \\
\hline & Adiantum sp.2 & Suplir keriting & Ornamental plant \\
\hline \multirow[t]{2}{*}{ Agavaceae } & Agave variegata & Agave variegata & Ornamental plant \\
\hline & Agave sp & Agave & Ornamental plant \\
\hline \multirow[t]{2}{*}{ Amaranthaceae } & Alternathera reineckii & Erpa & Ornamental plant \\
\hline & Celosia cistata & Jengger ayam & Ornamental plant \\
\hline \multirow[t]{2}{*}{ Amaryllidaceae } & Crynum asiaticum & Bakung & Ornamental plant \\
\hline & Zephyranthes candida & Bunga bawang & Ornamental plant \\
\hline Anonaceae & Polyalthia longifolia & Globokan tiang & Shading \\
\hline \multirow[t]{4}{*}{ Apocynaceae } & Alstonia shcolaris & Pulai & Shading \\
\hline & Pulmeria rubra & Kamboja bali & Ornamental plant \\
\hline & Adenium sp. & Kamboja jepang & Ornamental plant \\
\hline & Wrightia religiosa & Anting putri & Ornamental plant \\
\hline \multirow[t]{11}{*}{ Araceae } & Aglaonema crispum & Sri rejeki & Ornamental plant \\
\hline & Aglaonema picta & Beras tumpah & Ornamental plant \\
\hline & Aglaonema sp.1 & Snow white & Ornamental plant \\
\hline & Aglaonema sp.2 & Aglonema & Ornamental plant \\
\hline & Aglaonema sp. 3 & Aglonema lipstik & Ornamental plant \\
\hline & Anthurium crystallinum & Kuping gajah & Ornamental plant \\
\hline & Anthurium sp.1 & Gelombang cinta & Ornamental plant \\
\hline & Anthurium sp.2 & Anturium & Ornamental plant \\
\hline & Anthurium sp. 3 & Anturium kol & Ornamental plant \\
\hline & Epipremnum aureum & Sirih gading & Ornamental plant \\
\hline & Epipremnum aureum & Sirih gading variegata & Ornamental plant \\
\hline
\end{tabular}




\begin{tabular}{|c|c|c|c|}
\hline & variegata & & \\
\hline & Spathiphyllum sp. & Spatufilium & Ornamental plant \\
\hline & Zamioculcas zamiifolia & Daun dolar & Ornamental plant \\
\hline Araliaceae & Schefflera aboricola & Wali songo & Ornamental plant \\
\hline \multirow[t]{6}{*}{ Arecacea } & Crisalidocarpus lutenscens & Palem Kuning & Ornamental plant \\
\hline & Cyrtostachys renda & Palem merah & Ornamental plant \\
\hline & Dypsis lutescens & Palem Putri & Ornamental plant \\
\hline & Hyophorbe lagenicaulis & Palem Botol & Ornamental plant \\
\hline & Livistona saribus & Palem kipas & Ornamental plant \\
\hline & Phoenix roebelenii & Palem ponix & Ornamental plant \\
\hline \multirow[t]{6}{*}{ Asparagacceae } & Asparagus densiflorus & Ekor tupai & Ornamental plant \\
\hline & Chlorophytum comosum & Lili Paris & Ornamental plant \\
\hline & Cordilyne terminalis & Hanjuan Merah & Ornamental plant \\
\hline & $\begin{array}{l}\text { Dracaena marginata var } \\
\text { tricolor }\end{array}$ & Trikolor & Ornamental plant \\
\hline & Sansiviera trivasciata & Lidah mertua & Ornamental plant \\
\hline & Sansiviera sp. & Lidah mertua variegata & Ornamental plant \\
\hline \multirow[t]{4}{*}{ Aspleniaceae } & Asplenium scolopendrium & Kadaka & Ornamental plant \\
\hline & Asplenium nidus & Paku sarang burung & Ornamental plant \\
\hline & Asplenium sp.1 & Kadaka gelombang cinta & Ornamental plant \\
\hline & Asplenium sp.2 & Kadaka Keriting & Ornamental plant \\
\hline Athyriaceae & Diplazium sp. & pakis paku & Ornamental plant \\
\hline \multirow[t]{2}{*}{ Begoniaceae } & Begonia sp.1 & Begonia & Ornamental plant \\
\hline & Begonia sp.2 & Begonia coklat & Ornamental plant \\
\hline Bombacaceae & Durio zibethinus & Durian & Fruit resources \\
\hline Boraginaceae & Nemophila menziesii & Blue eyes & Ornamental plant \\
\hline \multirow[t]{4}{*}{ Bromeliaceae } & Bromelia sp. 1 & Bromelia hijau & Ornamental plant \\
\hline & Bromelia sp.2 & Bromelia lipstik & Ornamental plant \\
\hline & Bromelia sp. 3 & Bromelia coklat & Ornamental plant \\
\hline & Bromelia sp.4 & Giant & Ornamental plant \\
\hline \multirow[t]{2}{*}{ Cactaceae } & Epiphyilum oxipetalum & Wijaya kusuma & Ornamental plant \\
\hline & Opuntia cochenillifera & Centong & Ornamental plant \\
\hline Cannaceae & Canna discolor & Ganyong & Ornamental plant \\
\hline Casuarinaceae & Casuarina equisetifolia & Cemara udang & Ornamental plant \\
\hline \multirow[t]{2}{*}{ Combretaceae } & Combretum indicum & Melati belanda & Shading \\
\hline & Terminalia mantaly & Ketapang kencana & Shading \\
\hline \multirow[t]{2}{*}{ Commelinaceae } & Rhoeo discolor & Adam Hawa & Ornamental plant \\
\hline & Zebrina pendula & Sabrina & Ornamental plant \\
\hline
\end{tabular}




\begin{tabular}{|c|c|c|c|}
\hline Crassulaceae & Kalanchoe sp. & Cocor bebek & Ornamental plant \\
\hline \multirow[t]{4}{*}{ Cuppressaceae } & Cupressus sempervirens & Cemara lilin & Ornamental plant \\
\hline & Cupressus papuanus & Cemara Papua & Ornamental plant \\
\hline & Juniperus comunnis & Cemara Salju & Ornamental plant \\
\hline & Thuja occidentales & Cemara kipas & Ornamental plant \\
\hline \multirow[t]{2}{*}{ Cycadaceae } & Cycas revulota & Sikas & Ornamental plant \\
\hline & Cycas sp. & Pakis haji & Ornamental plant \\
\hline Echinoceae & Echinodorus palifolius & Melati Air & Ornamental plant \\
\hline \multirow[t]{4}{*}{ Euphorbiaceae } & Acalypha siamensis & Teh-tehan & Ornamental plant \\
\hline & Ecoecaria cochinchinensis & Sampang darah & Ornamental plant \\
\hline & Euphorbia pulcherrima & Kestuba & Ornamental plant \\
\hline & Codiaeum variegatum & Puring Kirana & Ornamental plant \\
\hline Equisetaceae & Equisetum debile & Bambu Air & Ornamental plant \\
\hline \multirow[t]{2}{*}{ Fabaceae } & Arachis pintoi & Kacang-kacangan & Ornamental plant \\
\hline & Bahunia purpurea & Butterfly & Ornamental plant \\
\hline Heloconiaceae & Heliconia paittacorum & Sepit udang & Ornamental plant \\
\hline Hemerocallidaceae & Dianella tasmanica & Lili brasil & Ornamental plant \\
\hline Hydrangeaceae & Hydrangea macrophylla & Brokoli hias & Ornamental plant \\
\hline Iridaceae & Neomarica longifolia & Iris & Ornamental plant \\
\hline \multirow[t]{2}{*}{ Lamiaceae } & Coleus blumei & Miana & Ornamental plant \\
\hline & Mentha $\times$ piperita & Daun mint & Medicinal plant, vegetable \\
\hline \multirow[t]{3}{*}{ Liliaceae } & Lilium sp. & Lili umbi & Ornamental plant \\
\hline & Ophiopogon japonicus & Ucai & Ornamental plant \\
\hline & Sansiviera sp. & Lidah mertua & Ornamental plant \\
\hline Lythraceae & Cuphea hyssopifolia & Taiwan & Ornamental plant \\
\hline \multirow[t]{2}{*}{ Malvaceae } & Hibiscus tiliaceus & Waru variegata & Ornamental plant \\
\hline & Hibiscus rosa sinensis & Spatu merah & Ornamental plant \\
\hline \multirow[t]{2}{*}{ Marantaceae } & Maranta arundinacea & Maranta & Ornamental plant \\
\hline & Calathea lutea & Talatea & Ornamental plant \\
\hline \multirow[t]{4}{*}{ Moraceae } & Ficus campanulata & Beringin Korea & Ornamental plant \\
\hline & Ficus sp.1 & Beringin sianto & Ornamental plant \\
\hline & Ficus sp.2 & Beringin variegata & Ornamental plant \\
\hline & Streblus asper & Serut & Ornamental plant \\
\hline \multirow[t]{5}{*}{ Myrtaceae } & Myrciaria cauliflora & Anggur Brazil & Ornamental plant \\
\hline & Psidium guajava & Jambu biji & Fruit resources \\
\hline & Syzygium oleana & Pucuk Merah & Ornamental plant \\
\hline & Syzygium jambos & Jambu mawar & Fruit resources \\
\hline & Syzygium malaccense & Jambu Jamaika & Fruit resources \\
\hline
\end{tabular}




\begin{tabular}{|c|c|c|c|}
\hline Nelumbonaceae & Nelumbo nucifera & Lotus pink & Ornamental plant \\
\hline Nyctagynaceae & Bougenvillea spectabilis & Bougenvilla bonsai & Ornamental plant \\
\hline Nymphaceae & Nymphaea sp. & Teratai & Ornamental plant \\
\hline Oleaceae & Jasminum sp. & Jasmin & Ornamental plant \\
\hline \multirow[t]{2}{*}{ Poaceae } & Bambusa vulgaris & Bambu kuning & Ornamental plant \\
\hline & Thryrsostachys siamensis & Bambu jepang & Ornamental plant \\
\hline \multirow[t]{2}{*}{ Piperaceae } & Piper betle & Sirih hijau & Medicinal plant \\
\hline & Piper crocratum & Sirih merah & Ornamental plant \\
\hline Polypodiaceae & Plathycerium bifurcatum & Paku tanduk rusa & Ornamental plant \\
\hline Portulacaceae & Portulaca glandiflora & Krokot & Ornamental plant \\
\hline Rosaceae & Rosa hybrida & Mawar pink & Ornamental plant \\
\hline \multirow[t]{4}{*}{ Rubiaceae } & Ixora siaminensis & Asoka pink & Ornamental plant \\
\hline & Ixora sp. 1 & Asoka kuning & Ornamental plant \\
\hline & Ixora sp.2 & Asoka putih & Ornamental plant \\
\hline & Mussaenda philipcica & Nusa indah & Ornamental plant \\
\hline \multirow[t]{3}{*}{ Solanaceae } & Capsicum frustecens & Cabe rawit Thailand & Spices \\
\hline & Capsicum annum & Cabe kecil & Spices \\
\hline & Solanum melogena & Terong & Vegetable \\
\hline \multirow[t]{6}{*}{ Rutaceae } & Citrus amblyacarpa & Jeruk limau & Spices \\
\hline & Citrus aurantiafolium & Jeruk nipis & Spices, medicinal plant \\
\hline & Citrus sinensis & Jeruk manis & Fruit resources \\
\hline & Citrus sp & Jeruk peras & Fruit resources \\
\hline & Evodia suaveolens & Jodiak & Ornamental plant \\
\hline & Murraya paniculata & Kemuning & $\begin{array}{l}\text { Ornamental plant, } \\
\text { medicinal plant }\end{array}$ \\
\hline \multirow[t]{2}{*}{ Sapindaceae } & Dimocarpus longan & Klengkeng & Fruit resources \\
\hline & Nephelium lappaceum & Rambutan & Fruit resources \\
\hline Urticaceae & Pilea cadieri & Mutiara & Ornamental plant \\
\hline Vitaceae & Vitis vinifera & Anggur hijau & Fruit resources \\
\hline \multirow[t]{4}{*}{ Verbenaceae } & Lantana camara & Lantana orange & Ornamental plant \\
\hline & Lantana montevidensis & Lantana pink & Ornamental plant \\
\hline & Lantana sp.1 & Lantana kuning & Ornamental plant \\
\hline & Lantan sp.2 & Lantana putih & Ornamental plant \\
\hline Zingeberaceae & Costus spicatus & Pacing & Ornamental plant \\
\hline
\end{tabular}

Based on the life form, the traded plants at the Jatikarya nursery are herbs, shrubs and trees. Herb is the plant which have the plant stems contain a lot of water and its size relatively smaller compared to other types. These types are a choice for consumers with small yard or home garden. Most of the traded herbs have attractive leaves (Aglonema spp., Bromelia spp., and Sansiviera spp.). 

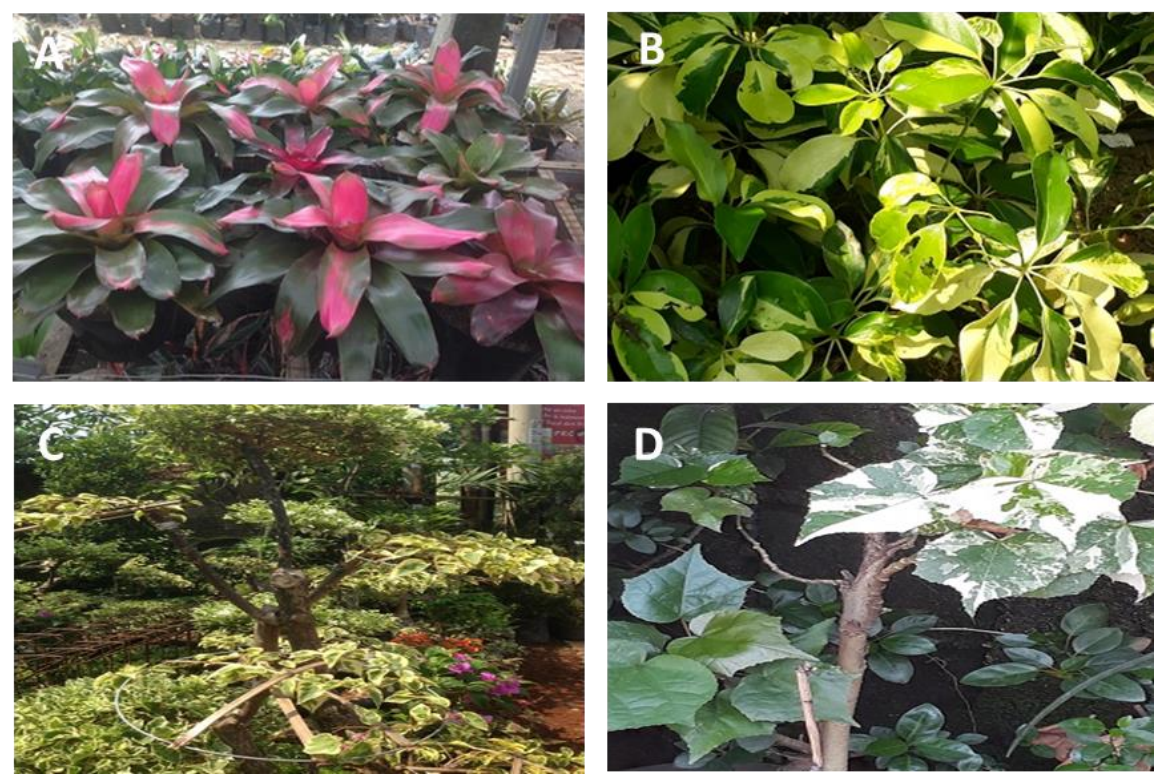

Figure 5 The types of habitus plant at the nurseryes of Jatikaya, Bekasi District, Java West Province, Indonesia. A. Herb

(Bromelia sp.); B. Shurb (Schefflera aboricola); C. Shurb (Bougenvillea spectabilis); D. Tree (Hibiscus tiliaceus).

Bonsai plants which the rootstock is different from the upper stem were traded plants at the nurseryes. The rootstock is large and sturdy, while the upper stem is a species with a dense branching pattern. To increase the number and size of clumps can be done by pruning (figure 5). The selling value of bonsai plants depends on the size and beauty of the structure of canopy.
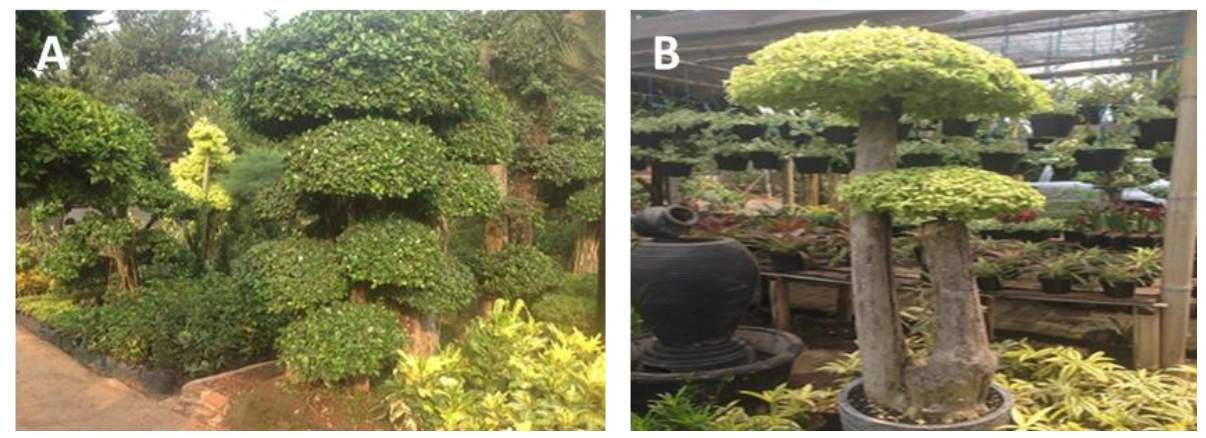

Figure 6 The types of bonsai plants are traded at the nursery of Jatikarya, Bekasi District, Java West Province, Indonesia. A. Bonsai of Korean banyan (Ficus campanulata); B. Bonsai of anting putri (Wrightia religiosa)

The selling price of the traded plants varies between Rp. 5,000 to millions of rupiah. Several factors that influence the selling price include size, age, availability, maintenance and its trend value. In general, plants are directly proportional to size, therefore plants with large size are higher than others.

Some of the plants have higher consumers such as rambutans (Nephelium lappaceum) and guavas (Psidium guajava) and mangos (Mangifera indica). These are common plants that easily can be found in yard and gardens because of the fruit times. The ornamental plants which high demand are plants that easy to care (Codiaeum variegatum, Equisetum debile), and attractive leaves (Aglaonema spp, Phylodendron spp).

\section{Conclusion}

The research founded more than 130 species of plants traded in the Jatikarya nursery have selling price from 5,000 $5,000,000$ IDR. The price of each type of plant depends to size, supply, age, method of breeding, and maintenance. Bonsai plants such as Korean banyan (Ficus campanulata/ Moraceae) and anting putri (Wrightia religiosa/ Apocynaceae) are expensive. Rambutans (Nephelium lappaceum) and guavas (Psidium guajava) are the type of fruit trees that have a great demand. 


\section{Compliance with ethical standards}

\section{Acknowledgments}

We are grateful to Lidia Sianturi and Tri Putri Marito for data collection in the field and for the nursery owners in Jatikarya, who provided information in this research. Our gratitude to the Institute for Research and Community Services (Lembaga Penelitian dan Pengabdian pada Masyarakat), Universitas Kristen Indonesia, which has promoted this research.

\section{Disclosure of conflict of interest}

The authors declare no conflict of interest.

\section{References}

[1] Kartawinata K. (2010). Dua abad mengungkap kekayaan floradan ekosistem Indonesia. In: Sarwono Prawirohardjo memorial lecture X. LIPI. 23 Agustus, Jakarta, 1-38.

[2] Silalahi M and Nisyawati. (2018a). The ethnobotanical study of edible and medicinal plants in the home garden of Batak Karo sub-ethnic in North Sumatra, Indonesia. Biodiversitas, 19(1), 229-238.

[3] Silalahi M, Nisyawati, Walujo EB, Supriatna J and Mangunwardoyo W. (2015). The local knowledge of medicinal plants trader and diversity of medicinal plants in the Kabanjahe traditional market, North Sumatra, Indonesia. Journal of Ethnopharmacology, 175, 432-443.

[4] Silalahi M and Nisyawati. (2018b). An ethnobotanical study of traditional steam-bathing by the Batak people of North Sumatra, Indonesia. Pacific Conservation Biology, 1-17.

[5] Iskandar BD, Iskandar J, Irawan B and Partasasmita R. (2018). Traditional markets and diversity of edible plant trading: Case study in Ujung Berung, Bandung, West Java, Indonesia. Biodiversitas, 19(3), 437-452.

[6] Haque MA, Miah MAM and Rashid MA. (2007). An economic study of plant nursery business in Gazipur and Jessore Districts of Bangladesh. Bangladesh J. Agril. Res. 32(3), 375-385.

[7] Sihotang H, Silalahi M and Simalango EM. (2019). Manajamen Tanaman Di Nursery Kranggan, Bekasi, Jawa Barat, Jurnal Pro-Life, 6(1), 89-101.

[8] Sihotang H and Silalahi M. (2019). Manajemen Keanekaragaman Tumbuhan Di Nursery Kota Bekasi sebagai Salah Satu Usaha Konservasi Tumbuhan. Laporan Hasil Penelitian, Universitas Kristen Indonesia, Jakarta.

[9] Basweti C, Lengkeek A, Prytz L and Jaenicke H. (2001). Tree nursery trade in urban and peri-urban areas A survey in Nairobi and Kiambu Districts, Kenya. Regional Land Management Unit (RELMA) ICRAF House, Gigiri, Nairobi Kenya.

[10] Singh RR, Meena LK and Singh P. (2017). High tech nursery management in horticultural crops: a way for enhancing income. Int. J. Curr. Microbiol. App. Sci., 6(6), 3162-3172.

[11] Silalahi M and Sihotang H. (2019). Keanekeragaman tumbuhan yang diperjual-belikan di nursery Kranggan, Bekasi, Jawa Barat, Jurnal Sainmatika, 6(1), 1-12.

[12] Backer CA and van Den Brink Jr. RCB. (1965). Flora of Java (Spermatophyte Only): Vol. II. Angiospermae, families 111-160.

[13] Backer CA and van Den Brink Jr. RCB. 1968. Flora of Java (Spermatophytes only). Vol. 3. Families 191-238.

\section{How to cite this article}

Silalahi M. (2019). The Plants Traded at the Nursery of Jatikarya, Bekasi District, West Java Province, Indonesia. GSC Biological and Pharmaceutical Sciences, 8(3), 85-93. 